\title{
A Framework Proposal for Analysis of Urbanization Policy
}

\author{
Nihal Ekin Erkan, (Associate Professor) \\ Marmara University, Turkey
}

doi: 10.19044/esj.2017.v13n14p24 URL:http://dx.doi.org/10.19044/esj.2017.v13n14p24

\begin{abstract}
This paper suggests a framework proposal for the analysis of urbanization policy as a public policy. Firstly, how urbanization policy is conceptualised is discussed. After, a framework for analysis of urbanization policy is suggested. Main elements of this framework are specified as (1) conditions that constitute urbanization policy background; urbanization logic produced by socio-economic structure; (2) political and administrative agents and other related actors and also their relations; forms of theoretically doing politics of actors; (3) key issue of urbanization policy and its prominent characteristics; process of urbanization policy; (4) change pattern of the policy. Paper ends up with an emphasis on an important inclusionary analysis for the development on urbanization policy making.
\end{abstract}

Keywords: Public policy, urban development, urbanization policy

\section{Introduction}

This paper puts forward a proposal framework for analysis of urbanization policy through discussing how urbanization policy is comprehended as a public policy.

Elements of public policy analysis can be specified to four fundamental groups, as suggested in the Walt-Gilson policy analysis framework, that are factors related to environment, content, process and actors (Walt-Gilson, 1994). This framework developed for the analysis of health reform and policies can be generalised and enlarged on different public policies as: 1) a) final stage in public administration: current role of public, b) society in which policy is developed: socio-economic structure, c) basic characteristics of the discussed policy issue; 2) a) current political and administrative agents and other related actors within the socio-economic structure: actors and their relations, b) forms of doing politics of actors: Relatability of these forms through main approaches or theories; 3) a) basic problems of the policy and their features: problem definition from the point 
of the citizens and the public, b) stages of the policy process: formation and implementation; 4) changes, outputs, effects and renewal of the policy.

Topic of the paper is the issue that how urbanization policy can be conceptualised and analyzed. Urban, urbanization and policy included by the concept of urbanization policy are primarily clarified in order to make explanation about urbanization policy conceptualisation. After this, main elements for urban policy analysis are specified and criticized.

\section{Analysis of urbanization policy}

Urban is a build environment and a social emergence; urbanization is a specific form of the main relation of the elements, space and society, that are main dimensions of this environment and emergence. Space is both a product and a producer of social relations (Lefebvre, 1991, Harvey, 2010)

Urbanization is a process specific to the connection of space and society or specific to the relation of population and space. Concentration of population in a settlement corresponds to concentration on population relations and also numerical increase on participants in the establishment of the space-society connection. This numerical increase also equals to a qualitative change. Urbanization is defined as an increse in the number of cities and people living in the city (Keleş, 2016); urbanization is defined as a change in human behavior and relationships (Wirth, 1938).

The emergence of a city as a historical and geographical contingency and as a gradual formation traces to 5000 BC. However, urbanization that meets condition of this formation's consolidation, contraction and increasingly expansion with a new speed and scale is synchronously addressed together with industrialization (Thorns, 2002).

As stated by Stren (2009), those interested in this worldwide revolution called urbanization firstly need to look at demografic statistics in order to understand sophistication of this phenomenon. "For those interested in the world-wide social revolution that we call urbanisation, the first step is in confronting the complexity this phenomenon is the consult aggregate demographic statistics.” (Stren, 2009)

Urban development is used for description of the situation in which realized increse and change take place as expected. This expected situation can be described as the actualization of needs and demands for increase in peace and life quality within the people's coexistence experience. This actualization is based on the legitimacy of public interest.

If politics is considered as the art of governing (Heywood, 2013), forming of coexistence conditions; urbanization policy can be considered as state decisions and actions on urban land production and control. This production and control are carried out in national scale and as in urban policy, urbanization policy includes decision making process at different 
levels rather than a subnational level, but urbanization policy gives priority to decision making process of centralized administration. While urban policy is about socio-politic-economic processes related to urban land (John, 2009), national urban policy is at the center of urbanization policy. This production and control of space, occured around main issues like migration and populating, is a continuous process that is directed by the state through legislation, tax and incentives.

To organize relationship between space and society by the state in a way that meets demands and needs of citizens (or not to organize); to solve urban problems (or not to solve) can be described as urbanization policy. In other words, it can be stated that urbanization policy is composed of decisions and actions carried out to achieve urban development. However, urban development is a counterfeiter process; meaning to meet mostly conflicting needs and demands of society and individual and also short termlong term needs and demands. Eliminating contradiction in a balanced and sustainable way brings out urban development.

Urbanization policy meets urban development to the extend that the policy serves ultimate aim of balanced and sustainable distribution of urban population among urban land that is a scarce resource (Yavuz, 1980). These actions contain both technical and political character. Thus, it can be said that these actions are attempts that do not only include actors from public sector, but include all the urban-related actors, all the city-dwellers as citizens. When the scope of the urbanization policy is extended in this way, concept of the politics can be found among all the power relations with its broad meaning (Heywood, 2013).

In this context, urbanization policy can be stated as an attempt undertaken by not only public institutions but by all the actors who are involved in the solution of the problem, raise social requests and try to put them on the agenda. In this situation, as an example, a housing type like a slum can be accepted as one of the output of urbanization policy, as a form of solution from the bottom for sheltering problem of city-dwellers. This acceptancy extremely expands the scope of urbanization policy analysis and variety of the actors included in the analysis. Another characteristic of urbanization policy that makes the policy analysis difficult is feature of the problems that constitute the basis for the policy.

Urban affairs that are expected to be solved by public authority include problems that cover collective consumption areas such as housing, health, transportation, education and that can be solved for many years. This situation displays main dilemmas of the policy. It is inevitable that actualization of legislative, administrative and financial arrangements for solutions of the problems takes time and policy is reproduced by telescopic decisions and actions. 
How can a framework be developed for the process of urbanization policy analysis that is long and full of uncertainties? While urbanization policy is analyzed, which questions should be asked and which matters should be focused on?

If elements referenced for the analysis of any public policy are arranged specific to the urbanization policy, following questions are encountered:

1) In a country where public policy is analyzed; what is the role of public and what is the conditions of public administration? What are the features of social and economic structure in which public policies takes part? How does the country become urbanized and today how does urbanization logic work?

2) a) Who are political and administrative makers using this structural heritage, in other words who are the actors institutionally making public policy and what are the features of these actors? How are the relationship networks among them? How do actors other than public institutions join in with these relations?

b) How can the forms of doing politics of actors be explained? Which public policy theories share similarity with decision making mechanisms and condition of agency? And which public policy theories such as rational comprensive, incremental and strategic can explain them better? (Lindblom, 1959, Faludi, 2013, Friedmann, 1987, Campbell\&Fainstein, 2005).

3) a) What is the situation in terms of the main problems of urbanization policy? What are the criterias with regards to the formulation and fulfilment of needs and demands and also what should the criterias be?

a. Balanced distribution of population on the area,

b. Actualization of social union as it minimizes urban affairs,

c. Supply of the social reinforcement areas suitable with life quality standards,

d. Fair distribution of urban resources,

e. Compatibility with town-dweller rights and urban rights

What are the criterias similar to these criterias mentioned above and what should the criterias be?

In the beginning, while describing what the urbanization policy is, there are important problems are encountered. Like O’Neil's saying “All politics is local", It is possible to say that "all questions and problems are urban". Moreover, there is permeable division between urban policy and urbanization policy, it would be surprising that a public policy that is not related with the urban is found. From the point of the citizen and public, there are various definitions of urban problems expected to be solved through the policy. Trying to overcome difficulties of definition might constitute an impediment for the analysis of urbanization policy. It will be 
useful to turn the discussion on "what is urbanization policy" into "how can urbanization policy be understood and improved?”. If knowledge generation is considered through the question of "how" besides the question of "what", it is possible to analyze urbanization policy as a process through analytical models.

b) How is urbanization policy analytically divided into categories and how are these categories analyzed? Analysis models based on process stages can be used in order to analyze stages of urbanization policy process. Although analysis models are examined in different titles such as Process Model, Garbage Can, Agenda Setting and Planning Stages (Cohen, March, Olsen, 1972, Birkland, 2014, Dye, 2012), analysis models are based on a common principle, "rational decision making”. As Cullingwort and Nadin (2002) point out, the concept of rationality also lies at the center of planning. Eventually, the basis for policy making is planning activity. It should be stated that planning is also the process of implementation of institutional information into action systematically (Friedman, 1987) and that this process can be analyzed through models.

It is possible to make interpretation of these models for urbanization policy as can be seen below:

- $\quad$ Proposing an issue for the agenda / Issue identification,

- Interpretation of the current situation by those concerned,

- Formation of alternatives, reconciliation/disagreement (process of politics),

- $\quad$ Generation of output decision : Preparation, adoption (bindingness) and dissemination of documents like legislation and plans,

- Implementation and concurrently making amendments on legal documents like legislation and plans.

Decision and action are intertwined in urbanization policy and there is a cyclical flow. The success of participation, capacity development and acupuncture projects that are the key pillars of NUP under the guidance of UN-Habitat (UN-Habitat, 2015) can be considered for all the processes of public policy.

4) How is the policy renewed? The policy is renewed and flows within this cyclical flow. This flow can be evaluated among the dynamics of urban legislation, urban economy, urban planning and design (UN Habitat, 2015). Constantly regenerated outputs of the urbanization policy are documents, built environment, socio-economic relations. In other words, urbanization policy is a dynamic process that produces cities and urban life that are constantly changing. This process reveals exchange values in the city and also reveals usage value in the sense of individual and public needs. Therefore, the process produces reproduction conditions. Which exchange and usage value that are attached importance by urbanization policy and the 
cost of this importance should be introduced. It is needed to critically discuss and remake urbanization policy.

\section{Conclusion}

Urbanization policy is one of the most important policies because of its distinctive and strong place for resource allocation (Urbanization policy includes planning authority that can make resource allocation without using resources). In addition, because there is strong relation between public policies and urban affairs, it can be said that it is not possible to determine a public policy independent from the urban. Thus, urbanization policy is at the center of political and administrative discussions, when urbanization policy is evaluated with regard to today's response conditions of citizens. Production of knowledge about urbanization policy and critically examining of the knowledge production conditions are important for the contribution to a better urbanization policy. Understanding cause and effect relation between what is done through urbanization policy and its outputs, and identifying problems of policy are important points for ensuring improvement for the policy. While urbanization policy is constantly changing together with cities, it is necessary to understand and overcome problematic elements in order to ensure this change in the direction of improvement. Covering a distance in the urbanization policy analysis will be the first step for building livable and sustainable cities.

\section{References:}

1. Birkland, T. A. (2014). An introduction to the policy process: Theories, concepts and models of public policy making. London, New York: Routledge.

2. Campbell, S., \& Fainstein, S. S. (2005). Readings in Planning Theory. Oxford: Blackwell.

3. Cohen, M. D., March, J. G., \& Olsen, J. P. (1972). A garbage can model of organizational choice. Administrative science quarterly, 125.

4. Cullingworth, J. B., \& Nadin, V. (2002). Town and Country Planning in the UK. London, New York: Routledge.

5. Dye, T. R. (2012). Understanding public policy. Yorkshire: Pearson.

6. Faludi, A. (2013). A reader in planning theory (Vol. 5). Elsevier.

7. Friedmann, J. (1987). Planning in the public domain: From knowledge to action. Princeton University Press.

8. Harvey, D. (2010). Social justice and the city (Vol. 1). University of Georgia Press.

9. Heywood, A. (2013). Politics. Palgrave.

10. John, P. (2009). Why study of urban politics. Theories of Urban 
Politics, 17-24.

11. Keleş, R. (2016). Kentleşme Politikası. Ankara: İmge.

12. Lefebvre, H. (1991). The production of space (Vol. 142). Oxford: Blackwell.

13. Lindblom, C. E. (1959). The science of" muddling through". Public administration review, 79-88.

14. Stren, R. (2009). Globalisation and urban Issues in the Non-Western World. Theories of Urban Politics, 153-168.

15. Thorns, D. C. (2002). The transformation of cities. Nova Iorque: Palgrave.

16. UN-Habitat. (2015) National Urban Policy: A Guiding Framework. HS Number: HS/090/15E.

17. Walt, G., \& Gilson, L. (1994). Reforming the health sector in developing countries: the central role of policy analysis. Health policy and planning, 9(4), 353-370.

18. Wirth, L. (1938). Urbanism as a Way of Life. American journal of sociology, 44(1), 1-24.

19. Yavuz, F. (1980). Kentsel topraklar:(ülkemizde ve başka ülkelerde). Ankara: SBF Basın ve Yayın Yüksek Okulu Basımevi. 